\title{
Contamination of sediment trap fluxes by vertically migrating phototrophic micro-organisms in the coastal Baltic Sea
}

\author{
Anna-Stiina Heiskanen* \\ Tvärminne Zoological Station, University of Helsinki, FIN-10900 Hanko, Finland
}

\begin{abstract}
Sedimentation rates of phytoplankton and particulate organic carbon (POC) were studied in the northern Baltic Sea, SW coast of Finland, during the spring bloom and early summer periods in May and June 1988. Sediment traps were moored at 15 and $30 \mathrm{~m}$ depths, and the cylinders were either preserved with formaldehyde (F) or remained as unpreserved control cylinders (C). The phytoplankton spring bloom in May was dominated by motile dinoflagellates. Due to the high abundance and vertical migration of the chain-forming dinoflagellate Peridiniella catenata, the POC fluxes measured by the F-cylinders were, on average overestimated by $12 \%$, and at most by $32 \%$ during the spring period. Between 3 and $12 \%$ of the $P$. catenata population was estimated to migrate daily below $15 \mathrm{~m}$ depth; part of the population also reached $30 \mathrm{~m}$ depth. Another migrating phototrophic organism present in the water column was the ciliate Mesodinium rubrum. Generally, a larger fraction of the $M$. rubrum population ( 2 to $26 \%$ ) migrated, but they did not contaminate the measurements to the same degree as $P$. catenata $(<3 \%$ of total POC fluxes) due to their lesser abundance in the water column. In June, Eutreptiella sp. (Euglenophyceae) had significantly higher cell numbers in the F- than in the C-cylinders. They were estimated to contaminate the POC fluxes up to $13 \%$ at $15 \mathrm{~m}$ depth (F-cylinder). The difference in the Eutreptiella cell numbers between the 2 treatments could have been partly due to increased copepod grazing rates inside the C-cylinders (up to $90 \%$ of the total difference if they fed on phytoflagellates only). Contamination caused by the total apparent vertical migration of $P$. catenata, $M$. rubrum and Eutreptiella sp. accounted for 17 and $12 \%$, on average, of the total POC sedimentation (F-Cylinders) at 15 and $30 \mathrm{~m}$ depths, respectively. This study indicates that vertical migration of the phototrophic microorganisms can significantly bias sediment trap measurements in shallow coastal areas where sediment traps are often deployed within the vertical range of the migrating microplankton (i.e. above 30 to $40 \mathrm{~m}$ ).
\end{abstract}

KEY WORDS: Sediment traps - Sedimentation - Preservation - Swimmer contamination - Vertical migration $\cdot$ Dinoflagellates $\cdot$ Mesodinium rubrum $\cdot$ Eutreptiella sp.

\section{INTRODUCTION}

Sediment traps are widely used in oceanic and coastal environments to measure the vertical flux of particulate material in the water column. These measurements are used to estimate $\mathrm{C}$ and $\mathrm{N}$ loss rates from the euphotic surface layer (e.g. Taguchi \& Hargrave 1978, Eppley et al. 1983, Wassmann 1991), as well as to approximate the $\langle f\rangle$ ratio, i.e. new production (or export production) to total primary production (e.g. Eppley et al. 1983, Wassmann 1990).

- Present address: Finnish Environment Agency, PO Box 140 , FIN-00251 Helsinki, Finland
Different kinds of poisons or preservatives are often used inside the sediment trap arrays in order to prevent loss of organic material by microbial decomposition and by zooplankton grazing during the intervals between sampling. When these substances are used, contamination by vertically migrating zooplankton (generally called 'swimmers') can be a serious problems as they may constitute a major part of the measured settling flux (Knauer et al. 1984, Lee et al. 1988, 1992, Hedges et al. 1993). In particular, 'cryptic swimmers' (i.e. mainly gelatinous zooplankton, Michaels et al. 1990) and vertically migrating protozoa and larvae (Dale 1989), which cannot be removed by picking or sieving, can considerably influence the sediment trap 
measurements. An additional source of contamination, also very difficult to separate from the total flux, is the evacuation of gut contents by mesozooplankton swimmers when they hit the preservative or hypersaline solution inside the sediment traps (Peterson \& Dam 1990). It is likely that during short-term deployments preserved sediment trap measurements are more biased due to contamination by planktonic swimmers than due to microbial decomposition when no preservatives are used (Lee et al. 1992, Hedges et al. 1993).

Daily vertical migrations are common among phytoplankton species and other phototrophic micro-organisms inhabiting aquatic environments (Heaney \& Butterwick 1985, Lindholm 1985, Stoecker et al. 1989). It has been suggested that the ability of autotrophic micro-organisms to migrate into the nutrient-rich deep layers during the night and to return to the surface layer during day provides them with a competitive advantage over the non-motile species in a stratified water column (Eppley et al. 1968, Cullen \& Horrigan 1981, Heaney \& Butterwick 1985). Diurnal vertical migration of phototrophic organisms is conitolied by severdi faciors inciuding phototaxis, geotaxis, nutrients, temperature and diurnal internal periodicity (Eppley et al. 1968, Cullen \& Horrigan 1981. Heaney \& Eppley 1981, Lindholm 1985). The swimming speeds of the migrating species and the length of their daily vertical distance traversed are species specific and controlled by adaptations to prevailing environmental factors like temperature, salinity, and stratification (Blasco 1978, Lindholm 1985, Kamykowski \& McCollum 1986).

Recently, different kinds of devices have been developed to prevent vertically migrating organisms from contaminating sediment traps measurements. These devices include the 'labyrinth of doom' which separate the mesozooplankton swimmers from passively sinking material by collecting them into different chambers (Coale 1990). In addition, a new sediment trap, equipped with a rotating sphere valve which removes passively sinking particles into a sealed chamber and leaves the swimmers outside, has been developed (Peterson et al. 1993). These devices (particularly the latter) efficiently separate large mesozooplankton swimmers from settling material. However, the authors did not investigate whether these devices were capable of excluding vertically migrating micro-organisms, such as phytoflagellates or microzooplankton, from passively sinking material.

In the present paper, I focus on the sediment trap biases caused by vertically migrating phototrophic organisms, i.e. autotrophic 'swimmers'. Micro- and nanosized phototrophic organisms are generally considered part of the sinking flux, and, hence, no attempts are made to estimate separately the contribution of verti- cally migrating phytoflagellates to the total vertical flux of organic matter. However, in many coastal areas where the depth of the mixed surface layer as well as the photic zome can be relatively shallow, contamination by vertically migrating micro-organisms can be anticipated, particularly when the upper sediment traps are positioned at depths within their vertical scale of diurnal migration (Dale 1989). In the present study, sediment trap contamination caused by vertically migrating phytoflagellates (a dinoflagellate, Peridiniella catenata, and a Euglenophycean, Eutreptiella $\mathrm{sp}$.) and by the phototrophic ciliate Mesodinium rubrum during the spring bloom and eariy summer in the coastal Baltic Sea is evaluated. In addition, the possible effects of microbial decomposition and mesozooplankton grazing on the observed differences between F- and C-cylinders are estimated. Primary productivity, pelagic community succession, sedimentation of organic carbon, and the dynamics of the carbon flow in the pelagic food web during the spring bloom have been reported earlier by Lignell et al. (1993).

\section{MATERIAL AND METHODS}

Study area. The sampling site was located in the outer coastal zone about $6 \mathrm{~km}$ off the SW coast of Finland $\left(59^{\circ} 47^{\prime} \mathrm{N}, 23^{\circ} 20^{\prime} \mathrm{E}\right.$ ) at the entrance into the Gulf of Finland (Baltic Sea). Salinity in the study area is generally between 5 and 7 psu. Salinity and temperature variations can be caused by upwellings and downwellings, as well as by surface water flow from the inner archipelago region during spring (Haapala 1994). The sampling site was a $46 \mathrm{~m}$ deep, relatively large basin surrounded by shallows and small rocky islets (Lignell et al. 1993).

Water column sampling. Water samples were taken weekly during the period from 29 March until 30 June 1988 , from depths of $0,2.5,5,10,15,20,30$ and $40 \mathrm{~m}$. The water column was always sampled between 8:00 and 10:00 h. Salinity was measured with an Autosal Laboratory salinometer, model 8400 . Nutrients $\left(\mathrm{NO}_{3}{ }^{-}\right.$, $\mathrm{PO}_{4}{ }^{2-}$ ) were measured according to Grasshoff (1983). Chlorophyll a samples were filtered on Whatman GF/F glass-fiber filters, sonicated and extracted in $94 \%$ ethanol for $24 \mathrm{~h}$ in total darkness. Chlorophyll a concentration of the extract was measured with a filter fluorometer (Turner Sequoia), which was calibrated using pure chlorophyll a (Sigma) as reference. Water samples from the depths between 0 and $15 \mathrm{~m}$ (surface layer) were pooled for phytoplankton cell counts and biomass determinations and preserved with Lugol's acid solution.

Sedimentation measurements. Settled material was collected for ca $1 \mathrm{wk}$ intervals from 30 April to 15 June 
in cylindrical sediment traps moored at 15 and $30 \mathrm{~m}$ depths. During the period between 25 May and 1 June, sediment traps were not deployed due to technical problems. Sediment traps had an aspect-ratio of 10 (height $100 \mathrm{~cm}$ ). Concentrated, non-buffered formaldehyde (37\%) was added through an external diffusion chamber $(50 \mathrm{ml})$ above the conical bottom section of one trap (F-cylinder), while the other trap was a nonpreserved control ( $\mathrm{C}$-cylinder). The maximum formaldehyde concentration was calculated to be $3.7 \%$ assuming that all the formaldehyde had diffused into the bottom section of the F-cylinder (total volume $500 \mathrm{ml}$ ). Formaldehyde concentration of $0.11 \%$ is sufficient to suppress bacterial activity down to $1 \%$ of the unpreserved control (Lee et al. 1992). Thus, $2 \mathrm{ml}$ formaldehyde (formaldehyde concentration: $0.15 \%$ ) would have been enough to retard microbial decomposition.

After retrieval, a volume of $1 \mathrm{l}$ from the upper part of the cylinder was discarded, and the remainder (ca 7.5 l) was collected through the opening from the funnel-shaped bottom of the sediment trap cylinder. In the laboratory the total volume of the sample was adjusted to $8 \mathrm{l}$ with filtered seawater. Subsamples (50 to $100 \mathrm{ml}$ ) for the chemical and microscopical analyses were taken from the homogeneous suspension. Samples for particulate organic carbon (POC) were analyzed by Heraeus CHN analyser as described by Lignell et al. (1993). Mesozooplankton carcasses were picked from the POC filters (F-cylinders) using forceps under a stereomicroscope (magnification: 60 to $120 \times)$.

Phytoplankton. Buffered formaldehyde ( $2 \%$ final concentration) was added to the subsamples for phytoplankton counts from the preserved sediment trap cylinders, whereas the subsamples from the control cylinders were preserved with Lugol's acid solution. Phytoplankton cells were enumerated under 125 and $312 \times$ magnification using an inverted microscope. At least 50 or 100 units (cells, chains or colonies) of the most abundant micro- and nanoplanktonic species were counted, and the species-specific 95\% confidence limits of the cell counts were calculated (Lund et al. 1958, Venrick 1978). From each sample a total of 500 counting units were enumerated. The resting cysts of Scrippsiella hangoei (Schiller) Larsen (syn. Peridinium hangoei) were enumerated using polarized light (Reid \& Boalch 1987. Heiskanen 1993).

The phytoplankton plasma volume and carbon-biomass values were calculated according to Strathmann (1967) and Sicko-Goad et al. (1977) but modified as suggested by the Baltic Marine Biologists (Edler 1979) and by Kononen et al. (1984). The conversion factor from cell volume to carbon biomass was 0.13 for dinoflagellates and for the cysts of Scrippsiella hangoei (Schiller) Larsen and 0.11 for all other phytoplankton groups (cf. Edler 1979). Detrital POC was calculated by subtracting the total phytoplankton carbon settled from the sedimentation rates of total POC.

The sedimentation rates of phytoplankton carbon biomass and detrital carbon measured by the C-cylinders were corrected for decomposition inside the sediment traps using the following equation:

$$
S=k C /\left(1-\mathrm{e}^{-k \tau}\right),
$$

where $S$ is the daily sedimentation rate $\left(\mathrm{mg} \mathrm{C} \mathrm{m}^{-2} \mathrm{~d}^{-1}\right)$ corrected for the loss of organic carbon through respiration, $C$ is the measured deposition of organic carbon in the $\mathrm{C}$-cylinder $\left(\mathrm{mg} \mathrm{C} \mathrm{m}^{-2}\right)$ during a collection period of $t$ days, and $k$ is the decay rate coefficient $\left(0.05 \mathrm{~d}^{-1}\right.$; Iturriaga 1979, Heiskanen \& Leppänen 1995)

Mesozooplankton. The numbers of mesozooplankton swimmers trapped in the F-cylinders were enumerated after 13 May under a stereomicroscope (magnification 60 to $120 \times$ ) by concentrating 400 to $1200 \mathrm{ml}$ of the suspension. The biomass of calanoid copepods was estimated by measuring their prosome length and calculating their average individual carbon biomass by using the length-carbon biomass regressions obtained from the studies on Acartia bifilosa copepodites and adults in the northern Baltic in May and June (Tanskanen 1994) and on Eurytemora affinis hirundoides copepodites and adults from the Baltic proper (Kankaala \& Johansson 1986). The biomass of harpacticoids was estimated using a wet weight (ww) of $8 \mathrm{mg}$ ind. $^{-1}$ (Viitasalo 1992) and a carbon content of $5.2 \%$ of the ww (Mullin 1969). Copepod grazing inside the C-cylinders was calculated by using a carbon consumption of $150 \%$ of the body $\mathrm{C} \mathrm{d}^{-1}$ at $20^{\circ} \mathrm{C}$ (Kiørboe et al. 1985 , Durbin et al. 1990), adjusted to the in situ temperatures by using the $Q_{10}$-value of 2.4 (Durbin \& Durbin 1992). Moreover, it was assumed that the total number of copepods in the F-cylinders at the end of each collection interval represented a cumulative accumulation of a constant number of copepods which arrived into the C-cylinders daily.

\section{RESULTS}

\section{Hydrography}

The water column was thermally homogeneous ( 1 to $3^{\circ} \mathrm{C}$ ) until mid-May, when warming of the surface water (up to $8^{\circ} \mathrm{C}$ ) created a slight thermocline between 10 and $15 \mathrm{~m}$. Episodic salinity anomalies, caused by the outflow of low salinity surface water ( 2.7 to $5 \mathrm{psu}$ ) from the inner archipelago in early April and an upwelling of more saline bottom water (6.3 to $6.8 \mathrm{psu}$ ) in mid-April, were observed to result in short-term vertical stabilities of the water column (Fig. 1A). By the 

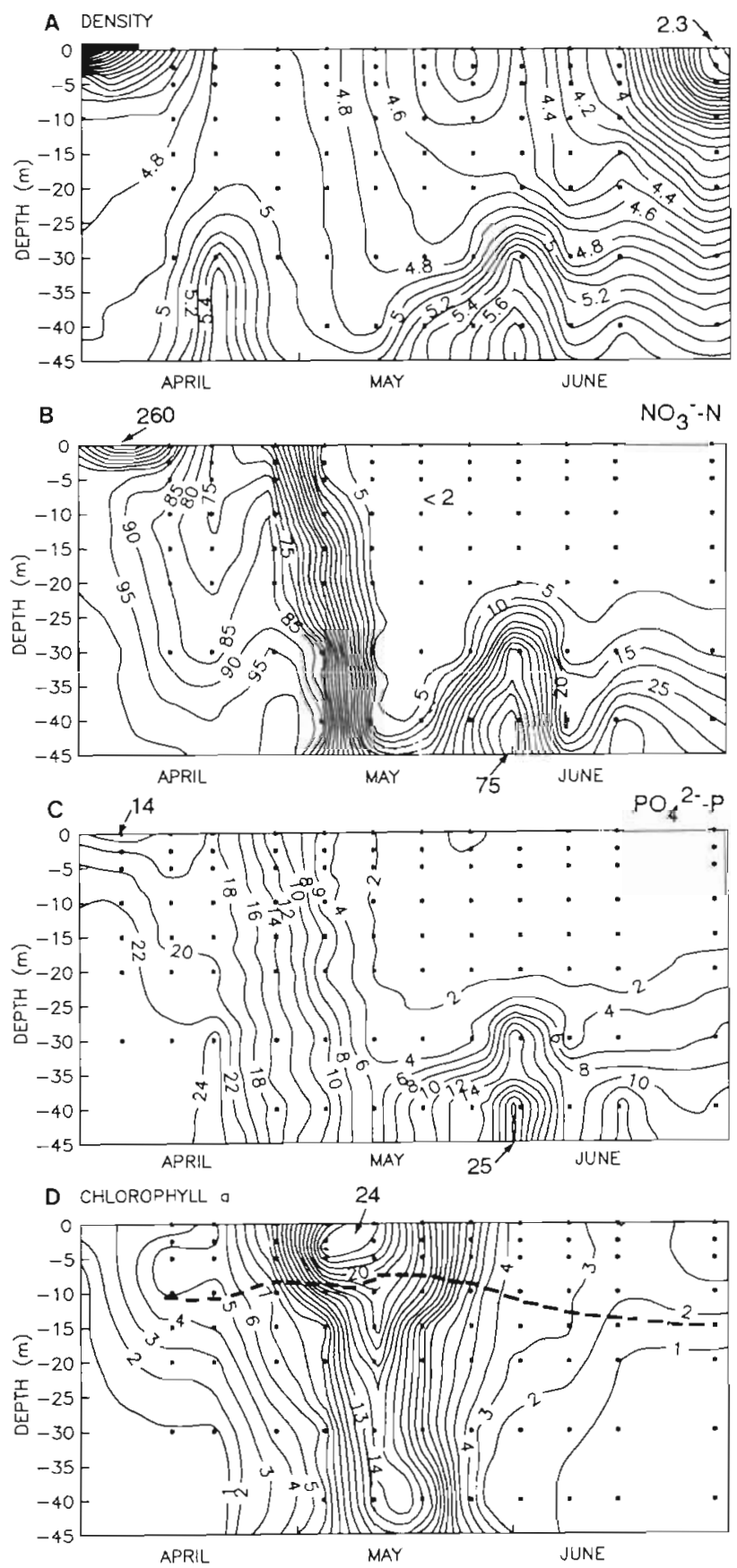

Fig. 1. Fluctuations of: (A) density (sigma-t; the horizontal bar in upper left corner denotes the duration of ice cover); (B) $\mathrm{NO}_{3}-\mathrm{N}\left(\mu \mathrm{gl}^{-1}\right)$; (C) $\mathrm{PO}_{4}{ }^{2}-\mathrm{P}$ ( $\left.\mu \mathrm{gl}^{-1}\right)$, and (D) chlorophyll a concentrations ( $\mu \mathrm{g} \mathrm{I}^{-1}$; depth of the 1 light level denoted with a dashed line) in the water column from 0 to $40 \mathrm{~m}$ depth during the study period between April and June

middle of May, nitrate and phosphate were utilized from the upper water column (Fig. 1B, C). In early June, an upwelling of more saline bottom water ( 6.3 to $7.4 \mathrm{psu}$ ) resulted in elevated nutrient levels below $20 \mathrm{~m}$ depth (Fig. 1A to C).

\section{Phytoplankton species composition and biomass}

Vertical distribution of phytoplankton biomass during each sampling occasion is illustrated by chlorophyll a concentrations in the water column. During the spring bloom biomass maximum in the middle of May (24.5 $\mathrm{mg} \mathrm{chl} \mathrm{m}^{-3}$ ), high chlorophyll a levels were found in the whole water column, while in June most of the biomass was concentrated in the upper $15 \mathrm{~m}$ (Fig. 1D).

Dinoflagellates dominated the spring bloom constituting approximately $90 \%$ of the total autotrophic biomass during the bloom peak $\left(740 \mathrm{mg} \mathrm{C} \mathrm{m}^{-3}\right.$; Fig. 2A, B), when Peridiniella catenata (Levander) Balech and Scrippsiella hangoei reached the respective maximum

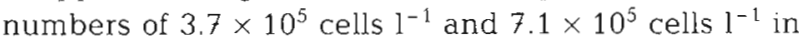
the $15 \mathrm{~m}$ deep surface layer. The most abundant diatoms were Achnanthes taeniata Grunow and Chaetoceros holsaticus Schüt, forming 10 to $30 \%$ of the total phytoplankton biomass in May (F1g. 2B). The phototrophic ciliate Mesodinium rubrum (Lohmann) Hamburger \& Buddenbrook was most abundant in early May, when its cell density in the 0 to $15 \mathrm{~m}$ layer was $0.3 \times 10^{5}$ ceís $i^{-1}$, yei, its contribution to the total

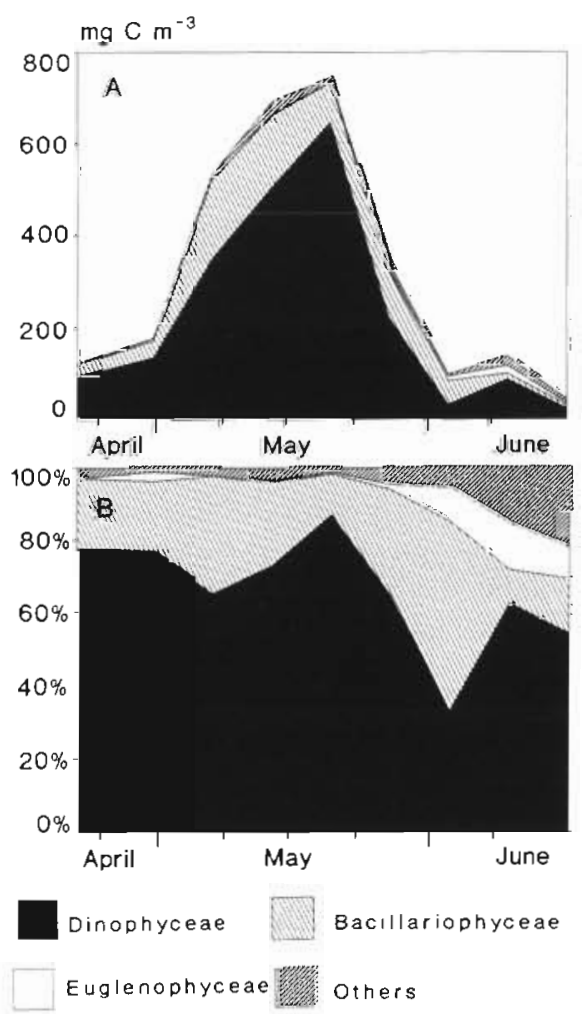

Fig. 2. (A) Total micro- and nanophytoplanktonic biomass ( $\mathrm{mg} \mathrm{C} \mathrm{m}^{-3}$ ) and (B) contribution of the major phytoplankton groups $(\%)$ to total biomass, in the surface layer $(0$ to $15 \mathrm{~m}$ ) from Apnl to June. Biomass of Mesodinium rubrum is included in 'Others' 

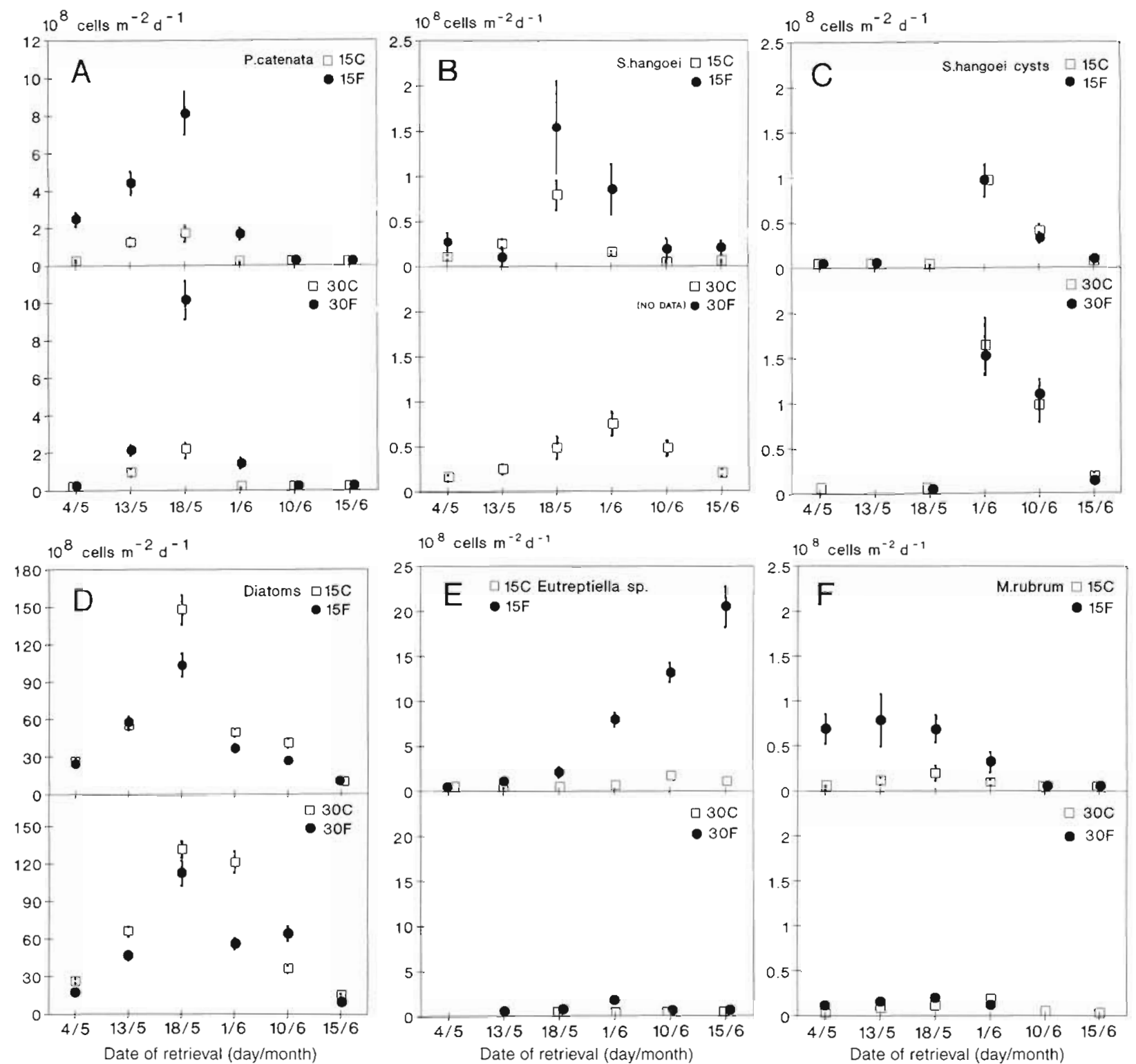

Fig. 3. Sedimentation rates of (A) Peridiniella catenata, (B) Scrippsiella hangoei, (C) S. hangoei cysts, (D) total diatoms, (E) Eutreptiella sp. and (F) Mesodinium rubrum (cells $\mathrm{m}^{-2} \mathrm{~d}^{-1}$ ) in formaldehyde (F) preserved and control (C) cylinders at 15 and $30 \mathrm{~m}$ depths during different sampling periods from May to June. Vertical bars indicate $95 \%$ confidence limits of the counts

autotrophic biomass was only $1 \%$ during this time. In early June, when phytoplankton biomass had declined, the relative contribution of $M$. rubrum increased to $4 \%$, although its cell numbers were relatively low $\left(0.1 \times 10^{5}\right.$ cells $\left.1^{-1}\right)$.

At the end of May, the diatom Skeletonema costatum (Greville) Cleve became the dominant species contributing ca $45 \%$ to the total phytoplankton biomass. Euglenophyceans (Eutreptiella sp.) were abundant in early June, constituting ca $10 \%$ of the total biomass (Fig. 2B) and reaching their maximum $\left(4.9 \times 10^{5}\right.$ cell $1^{-1}$ ) in the surface layer on 9 June.

\section{Deposition of phytoplankton and Mesodinium rubrum cells in sediment traps}

The cell numbers of Peridiniella catenata were significantly higher in the formaldehyde-preserved $(F)$ than in the control (C) cylinders in most of the samples (i.e. the $95 \%$ confidence limits did not overlap Fig. 3A). The highest deposition rates of $P$. catenata in the F-cylinders were measured between 13 and 18 May, being $8.1 \times 10^{8}$ and $10.1 \times 10^{8}$ cells $\mathrm{m}^{-2} \mathrm{~d}^{-1}$ at the respective depths of 15 and $30 \mathrm{~m}$. Scrippsiella hangoei was abundant in the sediment trap cylinders in 
Table 1. Geometric mean regression parameters for the square root transformed cell fluxes (cells $\mathrm{m}^{-2} \mathrm{~d}^{-1}$ ) in formaldehyde preserved $(Y)$ ys control $(X)$ cylinders (data from 15 and $30 \mathrm{~m}$ sediment traps are combined, $n=12$, except for the vegetative cells of Scripsiella hangoei where only data from $15 \mathrm{~m}$ was used; $\mathrm{n}=6$ ). SE: standard error of the slope LCL, UCL: lower $^{2}$ and upper $95 \%$ confidence limits of the slope, respectively

\begin{tabular}{lccccc}
\hline Species/group & $\mathrm{r}$ & Slope & SE & LCL & UCL \\
\hline $\begin{array}{l}\text { Peridiniella } \\
\quad \text { catenata }\end{array}$ & 0.94 & $1.95^{*}$ & 0.21 & 1.5 & 2.41 \\
$\begin{array}{l}\text { Eutreptiella sp. } \\
\text { Mesodinium }\end{array}$ & 0.90 & $3.75^{\circ}$ & 0.53 & 2.56 & 4.92 \\
$\quad$ rubrum & 0.63 & $2.44^{*}$ & 0.60 & 1.1 & 3.78 \\
S. hangoei cells & 0.76 & 1.38 & 0.45 & 0.59 & 2.17 \\
S. hangoei cysts & 0.99 & 1.02 & 0.04 & 0.93 & 1.12 \\
Diatoms & 0.88 & 0.78 & 0.20 & 0.52 & 1.05 \\
-Significantly different from 1 & & & \\
\hline
\end{tabular}

mid-May. Generally, the cell counts of S. hangoei were higher in the $\mathrm{F}$ - than in the C-cylinders, but the differeñce was clearly significant onlyy on 1 uccasion fFig. 3B). The identification of $S$. hangoei cells from the Fpreserved material was difficult as their cells probably deformed, becoming unrecognizable upon contact with formaldehyde. Therefore, statistically reliable counts were seldom obtained. Sedimentation rates of $S$. hangoei resting cysts were highest at the end of May, being $1.0 \times 10^{8}$ cysts $\mathrm{m}^{-2} \mathrm{~d}^{-1}$ at $15 \mathrm{~m}$ and $1.6 \times 10^{8}$ cysts $\mathrm{m}^{-2} \mathrm{~d}^{-1}$ at $30 \mathrm{~m}$ (C-cylinders) (Fig. 3C). There was no significant difference in the cyst numbers between the C-or F-cylinders.

The sedimentation rates of diatoms were often higher in the $C$ - than in the F-cylinders. The cell counts were significantly different in $50 \%$ of the samples (Fig. 3D). The maximum deposition of Eutreptiella sp. was observed between 10 and 15 June at $15 \mathrm{~m}$ depth in the F-cylinder. The cell counts of Eutreptiella sp. from F-cylinders were significantly different from that of the $\mathrm{C}$-cylinders at $15 \mathrm{~m}$ depth in late May and throughout June (Fig. 3E). The cell numbers of Mesodinium rubrum in the settled material were highest in early May (Fig. 3F). The difference was significant on 3 occasions for the traps at $15 \mathrm{~m}$ depth (Fig. 3F). Most of the cells identified in the F-cylinders had exploded; they were recognized due to the characteristic appearance of their cilia and because of the Cryptophycean chloroplasts around the ruptured cells.

Geometric mean regressions were calculated on the square root transformed deposition rates of the different species (Table 1). The regression parameters showed a significant enrichment (slope > 1) of Peridiniella catenata, Eutreptiella $\mathrm{sp}$. and $M$. rubrum into the F-cylinders, while the sedimentation rates of
Scrippsiella hangoei cells, S. hangoei cysts, and diatoms showed no significant difference between the F- and C-cylinders (Table 1). The intercepts of the regressions did not differ significantly from zero $(p>$ 0.1 ).

\section{Impact of vertical migration, microbial decomposition, and mesozooplankton grazing on the measured POC fluxes}

In mid-May, the maximum sedimentation rates of POC $\left(2.5\right.$ and $1.5 \mathrm{~g} \mathrm{C} \mathrm{m}^{-2} \mathrm{~d}^{-1}$ at $30 \mathrm{~m}$ depth in $\mathrm{F}$ - and C-cylinders, respectively) were recorded (Fig. 4A). Detrital POC dominated the flux of organic matter both in the $\mathrm{F}$-and $\mathrm{C}$-cylinders, being 50 to $70 \%$ of the total flux in May (Fig. 4B). The significantly higher total
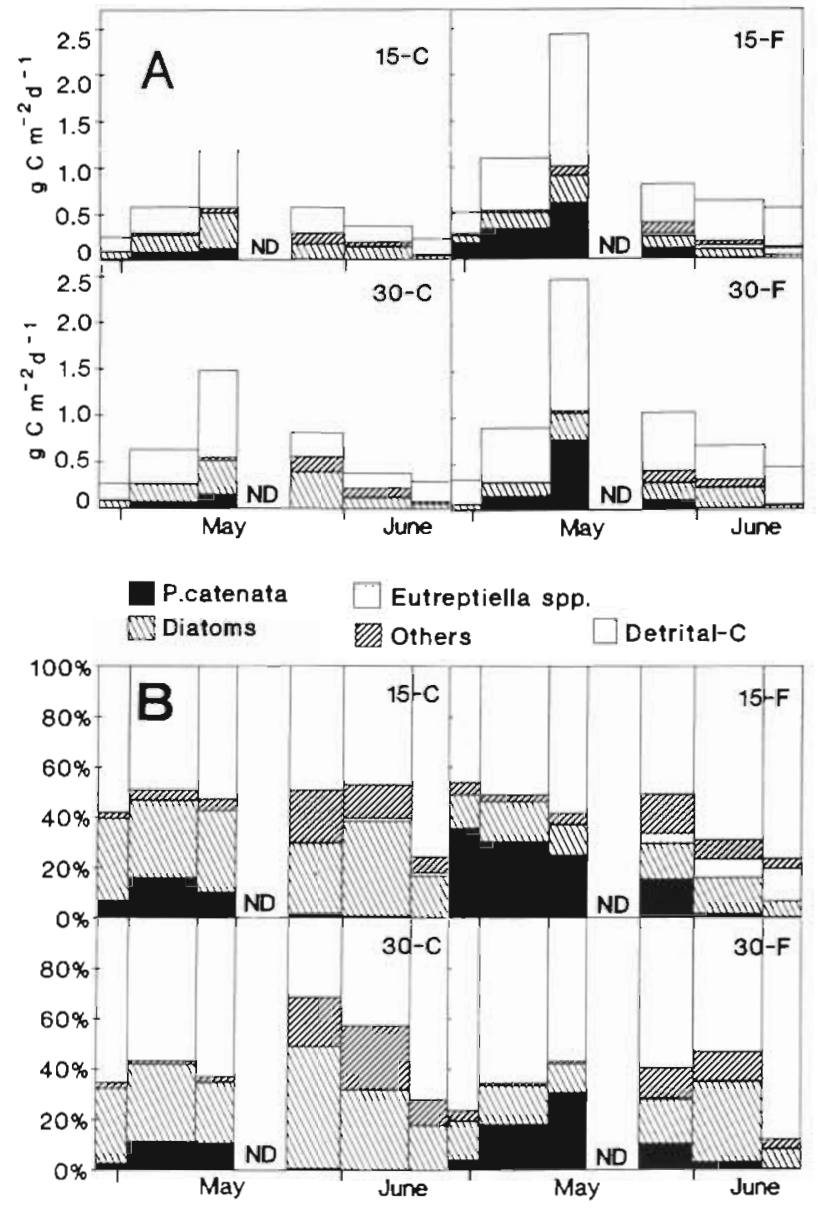

Fig. 4. (A) Sedimentation rates ( $\mathrm{mg} \mathrm{C} \mathrm{m} \mathrm{Cd}^{-2} \mathrm{~d}^{-1}$ ) of detrital-carbon and the major phytoplankton groups, and $(B)$ the contributions $(\%)$ of the different groups to total settled particulate organic carbon, at 15 and $30 \mathrm{~m}$ depth in the control (C) and formaldehyde $(F)$ preserved cylinders in May and June (bromass of Scrippsiella hangoei cysts and Mesodinium rubrum are included in 'Others'; ND: no data) 
Table 2. Calanoid and harpacticoid copepods. Numbers ( $\mathrm{n}$,

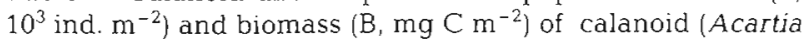
sp. and Eurytemora sp.) and harpacticoid copepods deposited in the $\mathrm{F}$-cylinder at 15 and $30 \mathrm{~m}$ depths during the different study periods after 13 May. Average in situ temperature ( $T$,

${ }^{\circ} \mathrm{C}$ ) during the sampling period is also denoted

\begin{tabular}{|lrrrrr|}
\hline Depth & \multicolumn{4}{c}{ Temp. } & \multicolumn{2}{c|}{ Calanoida } & \multicolumn{2}{c}{ Harpacticoida } \\
Date & $\left({ }^{\circ} \mathrm{C}\right)$ & $\mathrm{n}$ & $\mathrm{B}$ & $\mathrm{n}$ & $\mathrm{B}$ \\
\hline $15 \mathrm{~m}$ & & & & & \\
13-18 May & 4 & 51 & 45 & 15 & 2.2 \\
25 May-1 Jun & 6 & 170 & 355 & 15 & 2.2 \\
1-10 Jun & 7 & 280 & 678 & 10 & 1.5 \\
10-15 Jun & 7 & 122 & 255 & 1.7 & 0.3 \\
30 m & & & & & \\
13-18 May & 3 & 26 & 30 & 51 & 7.9 \\
25 May-1 Jun & 3 & 100 & 209 & 62 & 9.1 \\
1-10 Jun & 4 & 156 & 326 & 65 & 9.5 \\
10-15 Jun & 4 & 105 & 219 & 11 & 1.6 \\
& & & & & \\
\hline
\end{tabular}

phytoplankton biomass measured by F-cylinders (paired $t$-test: $t=2.23, \mathrm{p}=0.047, \mathrm{n}=12$ ), in comparison to the $\mathrm{C}$-cylinders, was in most cases due to Peridiniella catenata, which contributed from 4 to $36 \%$ of total POC flux in May (Fig. 4B). During the peak sedimentation of Scripsiella hangoei cysts, they contributed on average $10 \%$ to the total settled POC in both treatments and depths, while their vegetative cells never contributed more than $7 \%$ during the spring period. The proportion of diatoms was highest in the control cylinders (Fig. 4B), but the absolute amount of their biomass was more or less the same in both treatments (Fig. 4A). Resting spores of Achnanthes taeniata and Chaetoceros holsaticus dominated the settled diatom biomass in May.

The contamination of POC fluxes (F-cylinders) caused by the vertical migration of phytoflagellates and Mesodinium rubrum was estimated by subtracting the decomposition-corrected (Eq. 1) sedimentation rates in the $\mathrm{C}$-cylinders from the measured sedimentation rates in the $\mathrm{F}$-cylinders. On average, the estimated decomposition resulted in $18 \%$ higher rates than the measured sedimentation of phytoflagellates and $M$. rubrum in the C-cylinders.

The numbers of copepods increased strongly in the F-cylinders at the end of May (Table 2). Calanoid copepods (including Acartia sp. and Eurytemora sp.) were the most numerous $\left(26 \times 10^{3}\right.$ to $280 \times 10^{3}$ ind. $\left.\mathrm{m}^{-2}\right)$ in the trap cylinders while also harpacticoid copepods $\left(1.7 \times 10^{3}\right.$ to $65 \times 10^{3}$ ind. $\left.\mathrm{m}^{-2}\right)$ were also present in the sediment trap material (Table 2). The average prosome length of Acartia sp. (adults and copepodites) was $0.71 \mathrm{~mm}(\mathrm{SD}=0.14, \mathrm{n}=56)$ and that of Eurytemora sp. was $0.77 \mathrm{~mm}(\mathrm{SD}=0.07, \mathrm{n}=14)$. No other mesozooplankton groups (i.e. cladocerans or rotifers) were observed in the sediment trap samples. In mid-May, the estimated carbon consumption of copepods in the $\mathrm{C}$ cylinders was less than $1 \%$ of the total phytoflagellate and Mesodinum rubrum biomass difference between the C- and F-cylinders (i.e. total migration; Table 3), which suggested that copepod grazing was of minor importance in creating the difference between the 2

Table 3. Estimated POC fluxes ( $\mathrm{mg} \mathrm{C} \mathrm{m} \mathrm{m}^{-2} \mathrm{~d}^{-1}$ ) due to vertical migration of Peridiniella catenata, Eutreptiella sp., and Mesodinium rubrum (biomass fluxes in the F-cylinders from which the decomposition corrected fluxes in the C-cylinders are subtracted) and their contribution (\%) to the total POC flux in the F-cylinders (15 and $30 \mathrm{~m}$ depths) during different sampling periods in May and June. The total apparent migration is the sum of the P. catenata, Eutreptiella sp. and $M$. rubrum POC fluxes. Estimated copepod carbon consumption (copepod grazing, $\mathrm{mg} \mathrm{C} \mathrm{m}^{-1} \mathrm{~d}^{-1}$ ) in the C-cylinders during different sampling periods from $13 \mathrm{May}$ onwards (also expressed as percentage of total apparent migration; nd: no data)

\begin{tabular}{|c|c|c|c|c|c|c|c|c|c|c|}
\hline \multirow{3}{*}{$\begin{array}{l}\text { Depth } \\
\text { Date }\end{array}$} & \multicolumn{8}{|c|}{ Apparent migration } & \multicolumn{2}{|c|}{ Copepod grazing } \\
\hline & \multicolumn{2}{|c|}{ P. catenata } & \multicolumn{2}{|c|}{ Eutreptiella sp. } & \multicolumn{2}{|c|}{ M. rubrum } & \multicolumn{2}{|r|}{ Total } & \multirow[t]{2}{*}{ Rate } & \multirow[t]{2}{*}{$\%$ of total } \\
\hline & Flux & $\%$ of $\mathrm{POC}$ & Flux & $\%$ of POC & Flux & $\%$ of $\mathrm{POC}$ & Sum & $\%$ of $\mathrm{POC}$ & & \\
\hline \multicolumn{11}{|l|}{$15 \mathrm{~m}$} \\
\hline $30 \mathrm{Apr}-4 \mathrm{May}$ & 164 & 32 & 0 & 0 & 16 & 3 & 180 & 35 & nd & nd \\
\hline 4-13 May & 215 & 20 & 1 & $<1$ & 16 & 1 & 232 & 21 & nd & nd \\
\hline 13-18 May & 468 & 19 & 8 & $<1$ & 11 & $<1$ & 487 & 20 & 4 & $<1$ \\
\hline 25 May-1 Jun & 113 & 14 & 29 & 4 & 5 & $<1$ & 147 & 18 & 22 & 15 \\
\hline 1-10 Jun & 9 & 1 & 39 & 6 & 0 & 0 & 48 & 8 & 36 & 75 \\
\hline $10-15$ Jun & 3 & 1 & 70 & 13 & $<1$ & $<1$ & 73 & 13 & 25 & 34 \\
\hline \multicolumn{11}{|l|}{$30 \mathrm{~m}$} \\
\hline $30 \mathrm{Apr}-4 \mathrm{May}$ & 6 & 2 & 0 & 0 & 2 & $<1$ & 8 & 2 & nd & nd \\
\hline 4-13 May & 72 & 8 & $<1$ & $<1$ & 1 & $<1$ & 73 & 8 & nd & nd \\
\hline 13-18 May & 581 & 23 & 2 & $<1$ & 1 & $<1$ & 584 & 23 & 3 & $<1$ \\
\hline 25 May-1 Jun & 102 & 10 & 5 & $<1$ & 0 & 0 & 107 & 10 & 11 & 10 \\
\hline $1-10$ Jun & 20 & 3 & 1 & $<1$ & 0 & 0 & 21 & 3 & 14 & 64 \\
\hline 10-15 Jun & 2 & 0 & 2 & $<1$ & 0 & 0 & 4 & 1 & 16 & $>100$ \\
\hline
\end{tabular}


treatments during the spring bloom period (4 to 18 May). The contamination caused by vertical migration of Peridiniella catenata was estimated to contribute 8 to $32 \%$ of total settled POC in the F-preserved cylinders, while the vertical migration of $M$. rubrum never accounted for more than $3 \%$ during the spring bloom.

The highest contribution of the vertical migration of Eutreptiella sp. to total settled POC (F-cylinder) was $13 \%$, at $15 \mathrm{~m}$ depth in the middle of June (Table 3). In early June, the estimated copepod carbon consumption was equivalent to 75 and $64 \%$ of the total migration at 15 and $30 \mathrm{~m}$ depth, respectively (Table 3 ). This suggests that a considerable part of the difference between $F$ - and $C$-cylinders in June could have been. caused by copepod grazing on phytoflagellates in the C-cylinders.

\section{DİSCUSSSION}

Accumulation of the vertically migrating autotrophic phytoflagellates Peridiniella catenata and Eutreptiella sp., âs well as of the phototrophic ciliate Núsodinium rubrum, in the F-preserved sediment trap cylinders, was 4 to 14 times higher than in the control cylinders (Fig. 3A, E, F, Table 1). As the deposition rates of the passively sinking vernal diatoms and the resting cysts of Scrippsiella hangoei did not significantly differ between F-and C-cylinders (Fig. 3C, D, Table 1), this suggested that the accumulation of $P$. catenata, Eutreptiella sp., and $M$. rubrum cells could have been caused by their active swimming behavior into the $F$ preserved cylinders. However, this conclusion could have been emphasized by artifacts due to sediment trap methodology, sample preservation or inaccuracy in the cell counts. In addition, microbial decomposition and zooplankton grazing could have resulted in degradation of organic material and phytoplankton in the control cylinders. In the following discussion, the impact of these processes on the observed differences is evaluated.

\section{Replicability of sedimentation measurements and effect of sample processing}

The cylindrical shape and sufficiently high aspect ratio (height: diameter $=10$ ) of the sediment traps used in the present study fulfilled the basic requirements for good collection efficiency (Bloesch \& Burns 1980. Gardner 1980, Blomqvist \& Håkanson 1981) and prevented flushing from the bottom of the cylinders upon retrieval. Thus, the vortices created by passing currents, typically between 2 and $10 \mathrm{~cm} \mathrm{~s}^{-1}$ in the study area (Haapala 1994), could not reach the quiescent zone in the lower part of the cylinder (Bloesch \& Burns 1980).

The overall variability of measured fluxes for simultaneously deployed sediment trap arrays and replicate cylinders was checked in the archipelago region close to the present study site. The average fluxes of the 3 replicate cylinders, and the corresponding coefficient of variation of the total flux were calculated for sediment trap arrays which were moored at the same depth $(20 \mathrm{~m})$ and about $20 \mathrm{~m}$ apart from each others. The mean coefficient of variation between replicate cylinders varied between 2.4 and $18.1 \%$ with a mean of $8.8 \%(n=15)$ (Heiskanen et al. unpubl.). The obtained range of variability was slightly higher, but the average value $(8.8 \%)$ was in accordance with the results of Hedges et al. $(1988,1993)$, who found that the variation of total particulate material (TPM) flux between replicate arrays was, on average, $\pm 7.5 \%$ (total variation). Also the variation of the organic carbon percentage in the settled material was similar to that of TPM flux (Hedges et al. 1993). Based on the results of the above-mentioned studies, it was conciucted that replication belween paldilel cylinders within the same array was good and that the average total variation (coefficient of variation) was generally less than $10 \%$.

The major part of the sediment trap volume (>90\%) was used in processing of the samples. Mixing of the settled material from the quiescent zone in the trap bottom with the water in the upper part of the cylinder could have resulted in higher numbers of motile cells in the sample than were actually a part of the true flux. It was possible that their numbers were overestimated in relation to the numbers of passively sinking cells in the sediment trap samples. Migrating organisms which entered the sediment traps encountered lethal formaldehyde level inside the cylinders and sank rapidly to the bottom, whereas in the control traps they could remain in the upper part of the cylinder without sinking. As it was not known to what height in the cylinders formaldehyde diffused, it was considered reasonable to process as large a part of the trap volume as possible and to take subsamples from that. Since all the sediment trap samples were processed in the same manner, the problem caused by the dilution of the settled material was the same for both treatments.

\section{Accuracy of phytoplankton cell counts and effect of sample preservation}

The reliability of the cell counts depends on the number of counting units (cells, chains or colonies) enumerated per sample (Lund et al. 1958, Venrick 1978). In most cases, the number of units counted was 
sufficient to reveal significant differences between samples from F-and C-cylinders (Fig. 3). But since the true variation was not known due to the lack of replicate samples, the average coefficient of variation between sediment trap cylinders $(8.8 \%)$ has to be taken into account. When adding the variation of $8.8 \%$ to the calculated confidence limits of the cell fluxes, the differences between the 2 treatments become less notable in many cases. Nevertheless, the calculated geometric mean regressions between the cell fluxes obtained by F-and C-cylinders revealed that the enrichment in F-cylinders was significant for Peridiniella catenata, Mesodinium rubrum and Eutreptiella sp. (Table 1). Generally, the differences were so great for these species that it could not have been due to inaccuracy in cell counts or in the sediment trap methodology.

In order to elucidate whether any flagellated species were present in the deposited material, Lugol's acid solution was used to preserve $C$-cylinder samples. As the samples from $\mathrm{F}$-cylinders were already preserved by formaldehyde, only a small amount of buffered formaldehyde was added to ensure the further storage of the samples. Lugol's acid solution is generally considered to be a better preservative for phytoflagellates and for Mesodinium rubrum than either buffered or non-buffered formaldehyde (Taylor 1978, Throndsen 1978, Crawford 1989). This is mainly due to the more gentle storage of fragile cells, as well as to the better optical resolution and easier identification of flagellates under a phase-contrast microscope when preserved with Lugol's solution (e.g. Taylor 1978).

Despite formaldehyde preservation, significantly higher cell numbers of Peridiniella catenata, Eutreptiella sp., and Mesodinium rubrum were obtained in the F-cylinders. Yet, this was not necessarily the case for other flagellated species, especially those that do not have an organic theca around the cell membrane or which have very thin and delicate plates like Scrippsiella hangoei (Larsen et al. 1995), and are therefore more sensitive to formaldehyde. This type of species, when encountering formaldehyde inside the F-cylinders, either burst or are unrecognizably deformed and were therefore not included in the phytoplankton counts from the settled material. Moreover, an unknown fraction of $M$. rubrum cells probably explode upon preservation with formaldehyde, which will lead to an underestimation of $M$. rubrum cells in the sample (e.g. Crawford 1989). Consequently, if there had not been any mechanism for accumulating cells in the $\mathrm{F}$ cylinders (or loss of cells from the C-cylinders), preservation of the C-samples with Lugol's solution should had resulted in higher numbers of phytoflagellates and $M$. rubrum in the $\mathrm{C}$ - than in the F-cylinders.

The good agreement of results between the F-and C-cylinders obtained for the passively sinking Scripp- siella hangoei cysts (Fig. 3C, Table 1) showed that the replicability between the 2 cylinders and the cell counts was high. Since $S$. hangoei cysts were counted under polarized light, the visual differences caused by preservation with formaldehyde or Lugol's solution did not cause any problem. The polarization pattern typical for S. hangoei cysts (Heiskanen 1993) was easily distinguished among detrital material in both treatments. The cell numbers of diatoms were generally higher in the $\mathrm{C}$-cylinders, which indicated that diatoms were better distinguished in the control samples preserved with Lugol's solution than in the formaldehyde preserved material (slope $<1$ ). However. the difference was not large enough to be significant (Table 1).

\section{Microbial decomposition inside the $\mathrm{C}$-cylinders}

The total cumulative deposition of Peridiniella catenata was $1.6 \mathrm{~g} \mathrm{~m}^{-2}$ at $15 \mathrm{~m}$ (C-cylinder) during the study period. It was estimated to increase up to $1.9 \mathrm{~g} \mathrm{C}$ $\mathrm{m}^{-2}$ when corrected for decomposition (Eq. 1). Total deposition of $P$. catenata in the F-cylinder was $7.8 \mathrm{~g} \mathrm{C}$ $\mathrm{m}^{-2}$. Thus, a residue of $5.9 \mathrm{~g} \mathrm{C} \mathrm{m}^{-2}$, or $95 \%$ of the total difference between the $\mathrm{F}$ - and $\mathrm{C}$-cylinders, would still remain unexplained. At $30 \mathrm{~m}$ depth, the total deposition of $P$. catenata was 1.5 and $6.3 \mathrm{~g} \mathrm{~m}^{-2}$ in the $C$ - and F cylinders, respectively. Decomposition of $P$. catenata in the C-cylinder was estimated to be $0.3 \mathrm{~g} \mathrm{C} \mathrm{m}^{-2}$, which would leave $94 \%$ of the difference between $F$ and C-cylinders unexplained. Nor could the estimated total decomposition of the Eutreptiella sp. biomass inside the $\mathrm{C}$-cylinders account for the differences between the $\mathrm{F}$ - and $\mathrm{C}$-cylinders. The total deposition of Eutreptiella sp. biomass into the F-cylinders was $1.0 \mathrm{~g}$ $\mathrm{C} \mathrm{m}^{-2}$, and the decomposition corrected total cumulative deposition (at $15 \mathrm{~m}$ depth) was calculated to be $90 \mathrm{mg} \mathrm{C} \mathrm{m}^{-2}$. This would still leave a total difference of $98 \%$, or $910 \mathrm{mg} \mathrm{C} \mathrm{m}^{-2}$, unexplained during the study period. Accordingly, the total difference between the F- and C-cylinders for Mesodinium rubrum was $95 \%$ or $290 \mathrm{mg} \mathrm{C} \mathrm{m}{ }^{-2}$.

The decay rate of organic carbon measured as oxygen uptake of settled material was estimated to vary between 0.01 and $0.05 \mathrm{~d}^{-1}$ (mean: $0.02 \mathrm{~d}^{-1}$ ) during an earlier spring bloom study in the same area (Heiskanen \& Leppänen 1995). These values are in accordance with the decay rates of settled material obtained for the same temperature range $\left(1\right.$ to $\left.6^{\circ} \mathrm{C}\right)$ in other studies in the coastal Baltic (Iturriaga 1979) as well as in the upper ocean (Lorenzen et al. 1983). However, lower decomposition rates have also been measured ( $\leq 1 \%)$ in the deeper oceanic waters (>1000 m), but there too the sedimentation rates of organic material are low and the settled material has already gone through consid- 
erable degradation during sinking (Gardner et al. 1983). As the temperatures varied between 2 and $8^{\circ} \mathrm{C}$ during the present study, the uppermost value of the range $\left(0.05 \mathrm{~d}^{-1}\right)$ was considered to be a reasonable estimate which would not result in an underestimation of the decay rate inside the C-cylinders. Nevertheless, deformation and disintegration of cells could have been faster than mineralisation of organic carbon in the C-cylinders. Recognizable cellular structures of filamentous cyanophytes have been observed to disappear with rates between 10 and $25 \% \mathrm{~d}^{-1}$ at $20^{\circ} \mathrm{C}$. These rates were considerably faster than the simultaneous disappearance of organic carbon (Fallon \& Brock 1979). Even if the cell structures had disintegrated twice as fast as total organic carbon (i.e. $0.10 \mathrm{~d}^{-1}$ ) in the C-cylinders, $89 \%$ (or $5.5 \mathrm{~g} \mathrm{C} \mathrm{m}^{-2}$ ) of the total difference between $\mathrm{F}$ - and C-cylinders of Peridiniella catenata biomass, for instance, would still remdin unexplained. These calculations indicated that the microbial decomposition inside the $\mathrm{C}$-cylinders could not account for the difference between the treatments

\section{Mesozooplankton grazing inside the C-cylinders}

The impact of copepod grazing on the disappearance of settled phytoplankton biomass in the C-cylinders was estimated to be negligible in mid-May (Table 3). It was obvious that grazing could not have accounted for the Peridiniella catenata biomass difference between the 2 treatments. Moreover, the chain size of $P$. catenata in the sediment trap samples (generally 2 cells chain $^{-1}$ ) was slightly larger than the optimal food size of copepods (i.e. 2 to $5 \%$ of prosome length; Berggreen et al. 1988). Therefore, it was unlikely that copepods could feed effectively on $P$. catenata cells. During the first part of May, the impact of copepod grazing inside $\mathrm{C}$-cylinders was probably even smaller, since the biomass of copepods was still low in the water column (Lignell et al. 1993). Thus, the difference between Mesodinium rubrum biomass in the $\mathrm{F}$ - and $\mathrm{C}$-cylinders was merely due to vertical migration rather than to zooplankton grazing inside the $\mathrm{C}$-cylinders.

The numbers of calanoid copepods (Acartia sp. and Eurytemora sp. adults and copepodites) in the F-cylinders increased considerably in late May and June (Table 2), suggesting that if an equivalent amount of copepods had entered the $C$-cylinders, their grazing could have reduced settled phytoflagellate biomass significantly (Table 3). In June, the difference between $F$ - and C-cylinders was mainly caused by the accumulation of Eutreptiella sp. at $15 \mathrm{~m}$ depth. As the length of the Eutreptiella sp. cells (15 to $35 \mu \mathrm{m})$ was within the range of the optimal copepod food size, it was possible that grazing could have accounted for up to $92 \%$ of the biomass difference between $\mathrm{F}$ - and C-cylinders assuming that the copepods fed on Eutreptiella sp. only (Table 3).

Copepods were presumed to feed with maximum ingestion rates in the sediment traps where the food concentration was generally above the critical level (i.e. $>200 \mathrm{~g}$ phytoplankton-C $\mathrm{l}^{-1}$; Durbin \& Durbin 1992) throughout the study period. The maximum daily carbon ingestion of Acartia sp. has been reported to be ca $150 \%$ of the body carbon content at 18 to $20^{\circ} \mathrm{C}$ if fed on algal cultures which have an optimal particle size and concentration (Kiørboe et al. 1985, Durbin et al. 1990). Raptorial feeding behaviour of Acartia sp. could have resulted in selective grazing pressure on vertically migrating (fresh) phytoflagellates and protozoa (Jonsson \& Tiselius 1990), which are the preferred food of calanoids (Kleppel 1993, and references therein). Úsing the $\mathrm{Q}_{10}$-value of 2.4 (Durbin \& Durbin 1992), the maximum daily ingestion rates reduced to values varying between 34 and $48 \%$ of the body carbon, which were in accordance with the ingestion rates measuried at the saturating foou leveis for Acarila spp. at the same temperature (ca $4^{\circ} \mathrm{C}$ i Durbin et al. 1990 , Durbin \& Durbin 1992).

The epibenthic harpacticoid copepods could have had different food preferences than calanoids. Harpacticoid copepods have been reported to feed on several species of algae (including diatoms and phytoflagellates), benthic ciliates, and bacteria (Hicks \& Coull 1983, and references therein). As their biomass was generally much lower than that of calanoids, it was not considered necessary to estimate their daily carbon consumption separately. Thus, the grazing rates of calanoids and harpacticoids were estimated in the same way and pooled (Table 3 ).

The carbon biomass of copepods can vary considerably depending on the short-term food supply and quality (Durbin \& Durbin 1992). The biomass calculated using length-carbon biomass regressions may result in an over or underestimation of total biomass, even if the equations obtained from the same study area are used (Kankaala \& Johansson 1986, Tanskanen 1994). Yet, the uncertainty in the copepod carbon biomass-values was minor in comparison to other possible errors in the daily carbon consumption estimates. For instance, if copepods fed in the C-cylinders only after their diurnal descent from the surface layer (for ca $12 \mathrm{~h}$ ) and left the traps thereafter, the present estimates of copepod grazing would be overestimated by ca $50 \%$. Although the flux of dead copepods carcasses was not enumerated, only a few copepods were observed in the C-cylinders. Consequently, the error caused by including dead copepods into the biomass estimate from the F-cylinders was probably minor. 


\section{Vertical migration}

During the peak deposition of Peridiniella catenata in mid-May, approximately $12 \%$ of the average population in the upper water column was estimated to be trapped into the F-cylinders daily $(15 \mathrm{~m})$ due to vertical migration (Table 4). These values might have been overestimated due to the biomass below the $15 \mathrm{~m}$ depth (Fig. 1D), which could have influenced total deposition but was not included in the calculations. Moreover, the comparisons between temporally integrating sedimentation measurements and discrete water column samples are hampered by advection and vertical movements of water masses. Despite these problems, the estimated fractions of migrating populations were in accordance with the other observations from the central Baltic, where less than $20 \%$ of the vernal $P$. catenata population was found to migrate below $15 \mathrm{~m}$ daily. The range of their daily descent was observed to reach a depth of $30 \mathrm{~m}$, although only a small fraction (10 to $20 \%$ ) of the population migrated into the deeper water column (Passow 1991). Migrating dinoflagellates have been observed to swim with speeds of up to $2 \mathrm{~m} \mathrm{~h}^{-1}$, which would give a potential daily amplitude of $24 \mathrm{~m}_{12} \mathrm{~h}^{-1}$ (Kamykowski \& McCollum 1986). Moreover, chain formation increases the swimming speed of dinoflagellates by a factor of 1.5 to 1.6, when compared to single cells of the same species (Fraga et al. 1989). These laboratory studies support the implication that it was possible for $P$. catenata to traverse a daily vertical distance of $30 \mathrm{~m}$.

The dinoflagellate Scrippsiella hangoei often dominates vernal phytoplankton biomass together with Peridiniella catenata in the northern Baltic (Larsen et al. 1995). There are no direct observations on the vertical migration of $S$. hangoei, but sometimes it has been observed to form very dense under-ice blooms where the whole population is accumulated into the uppermost $0.5 \mathrm{~m}$ below the ice (Larsen et al. 1995). It can also form a very high spring bloom biomass and concentrate into a thin surface layer, probably favoured by high nutrient concentrations and density stratification (Heiskanen 1993). These observations suggest that $S$. hangoei is able to control its position in the water column and to perform vertical migrations.

In early May, up to $26 \%$ of the Mesodinium rubrum population in the surface layer was estimated to daily migrate below $15 \mathrm{~m}$ depth (Table 4). These results were slightly lower than but still comparable with the observations from the central Baltic, where approximately 40 to $50 \%$ of the $M$. rubrum population in the whole water column accumulated into the upper $10 \mathrm{~m}$ during the daytime, and about half of the population migrated downwards leaving ca 20 to $30 \%$ of the cells in the surface layer during the night. The vertical range of their daily descent reached the depth of 30 to $40 \mathrm{~m}$ (Passow 1991). Generally, a larger fraction of the M. rubrum than of the Peridiniella catenata population migrated, but due to the relatively small biomass of $M$. rubrum, their migratory behavior did not have such a noteworthy effect on the total sedimentation of POC as $P$. catenata did.

High cell numbers of Eutreptiella sp. only in the Fcylinder at $15 \mathrm{~m}$ suggested that they performed diurnal vertical migrations mainly in the upper water column. Many autotrophic Euglenophyceans are extremely phototrophic and perform diurnal phototactic movements controlled by photosensitive pigments in the eye-spot (Leedale 1967, and references therein). Eutreptiella gymnastica has been observed to swim at a speed of up to $1 \mathrm{~m} \mathrm{~h}^{-1}$ (Throndsen 1973). This speed would have enabled Eutreptiella sp. to execute vertical migrations with a daily amplitude of $12 \mathrm{~m}$ and to use the nutrients below the photic zone (Fig. 1B, C). Presuming that copepods fed on Eutreptiella sp. and Mesodinium rubrum cells in proportion to their biomass available for grazing in the sediment traps (i.e. total deposition in the F-cylinders), the fraction of the

Table 4. Peridiniella catenata, Eutreptiella sp., and Mesodinium rubrum. Deposition rates (cells $\mathrm{m}^{-2} \mathrm{~d}^{-1}$ ) in the formaldehyde preserved (F) and control (C) cylinders at $15 \mathrm{~m}$ depth, as a percentage of the average suspended cell numbers (cells $\mathrm{m}^{-2}$ ) above the trap in the $15 \mathrm{~m}$ deep surface layer The difference between the 2 loss rates $(F-C)$ represents the average fraction (\%) of the suspended population that was deposited daily due to vertical migration (values in parentheses are corrected for the estimated copepod feeding in the C-cylinders assuming that Eutreptiella sp. and $M$. rubrum were grazed in proportion to their availability in the sediment trap samples)

\begin{tabular}{|c|c|c|c|c|c|c|c|c|c|}
\hline \multirow[t]{2}{*}{ Date } & \multicolumn{3}{|c|}{ P. catenata } & \multicolumn{3}{|c|}{ Eutreptiella sp. } & \multicolumn{3}{|c|}{ M. rubrum } \\
\hline & F & $\mathrm{C}$ & $\mathrm{F}-\mathrm{C}$ & $\mathrm{F}$ & $\mathrm{C}$ & $F-C$ & $\mathrm{~F}$ & $C$ & $F-C$ \\
\hline 30 Apr-4 May & 8.7 & 0.8 & 7.9 & 3.8 & 5.3 & -1.5 & 27.9 & 1.5 & 26.4 \\
\hline 4-13 May & 9.6 & 2.6 & 7 & 10.8 & 4.3 & 6.5 & 27.6 & 3.9 & 23.7 \\
\hline 13-18 May & 14.8 & 3 & 11.8 & 18.1 & 1.5 & $16.6(13.9)$ & 24.2 & 7.1 & $17.1(12.9)$ \\
\hline 25 May-1 Jun & 9.5 & 0.9 & 9.6 & 31.1 & 2.1 & $29(11.4)$ & 12.8 & 3.7 & $9.1(1.1)$ \\
\hline 1 - 10 Jun & 6.1 & 1.8 & 4.3 & 25.2 & 3 & $22.2(1.9)$ & 1 & 0.9 & $0.1(0)$ \\
\hline $10-16$ Jun & 3.1 & - & 3.1 & 37.7 & 2.7 & $35.7(23.2)$ & 3 & 1.4 & $1.6(0.3)$ \\
\hline
\end{tabular}


populations performing vertical migration decreased accordingly (Table 4). In early June, when Eutreptiella sp. cells could have been heavily grazed by zooplankton in the $\mathrm{C}$-cylinder, the migrating population could have been considerably lower than otherwise estimated $(<2 \%)$. However, during the next period, more than $20 \%$ of the population appeared to migrate even if grazing was taken into account (Table 4). This indicated that, although the cells of Eutreptiella sp. could have been consumed by copepods, the difference between $\mathrm{F}$-and $\mathrm{C}$-cylinders was mainly caused by vertical migration rather than by grazing.

\section{Impact of the phototrophic swimmers on POC sedimentation rates and consequences for the spring bloom carbon budget}

Cotal sedmentation of organic carbon measured by F-cylinders was overestimated by 22 and $17 \%$ in 15 and $30 \mathrm{~m}$ depths, respectively, due to the contamination by vertically migrating dinoflagellates during lise vernal biuurn periud (30 April to 18 Míay). Afiter the spring bloom, phytoflagellate migration contaminated POC fluxes by 10 and $5 \%$, at the respective depths. Contamination by the apparent migration of phytoflagellates and Mesodinium rubrum in the F-cylinders accounted for $37 \%$, on average, of the measured $\mathrm{POC}$ flux difference between $\mathrm{F}$ - and $\mathrm{C}$-cylinders during the whole study period, while the estimated microbial decomposition and copepod grazing inside the $\mathrm{C}$ cylinders was accounted for additional $31 \%$ of the difference. The remainder could have been due to contamination caused by other vertically migrating phytoflagellates or by nano- and microsized protozoa and $M$. rubrum which had entered the F-cylinders and thereafter perished. In addition, evacuation of copepod gut contents upon contact with formaldehyde could have increased the sedimentation of detrital organic matter measured by F-cylinders (Petersen \& Dam 1990).

The total carbon loss by direct sedimentation of phytoplankton from the pelagic system was estimated to be $70 \%$ of the integrated primary production (i.e. $45.5 \mathrm{~g} \mathrm{C} \mathrm{m}^{-2}$ ) during the spring bloom in 1988, while the losses through the grazing food chain and through the microbial loop were minor (Lignell et al. 1993). In the carbon budget calculations, the POC sedimentation rates measured by the F-cylinder $(30 \mathrm{~m})$ were corrected for the vertical migration of Peridiniella catenata, which was the major contamination source in the sediment traps during the spring bloom period (Table 3). Without this correction the total integral POC sedimentation would have comprised $84 \%$ of the vernal primary production, which was clearly an overestimate and did not balance the carbon budget during the ver- nal bloom (Lignell et al. 1993). Nevertheless, the obtained integral value was higher than the export production reported by other investigations in the Baltic Sea 130 to $65 \%$ of the integral primary production). This result may reflect differences in the sediment trap configuration, trapping efficiency, and preservation (Peinert et al. 1982, Kuparinen et al. 1984, Larsson et al. 1986, Leppänen 1988, Heiskanen \& Leppänen 1995), while hydrodynamical properties and bottom topography of the study area are also likely to influence the comparability of different studies. However, true interannual variation in primary production and in the retention efficiency of the pelagic community, as well as the differences in the life cycle strategies of the dominating spring bloom phytoplankton species (Heiskanen \& Kononen 1994), may result in different ratios of the seasonal export production to total primary production, even when the studies from the same study area are compared (Kuparinen et ai 1984, Lignell et al. 1993, Heiskanen \& Leppänen 1995).

The evidence provided in the present study suggests that more attention should be paid to the contamination of sediment trap fluxes caused by autotrophic phytoflagellates and ciliated protozoa in the shallow coastal areas. This is especially the case if the use of poisons or preservatives cannot be replaced by frequent emptying or by any devices which would prevent vertically migrating micro-organisms entering the sediment trap. Microscopical analysis of the planktonic micro-organisms collected by the traps should be carried out as a routine procedure in sedimentation measurements.

Acknowledgements. I am indebted to Kjell Gundersen for his cooperation and help during this study. Torsten Sjolund provided invaluable help by constructing the sediment traps and taking care of the retrievals. Thanks are due to Elina Salminen and Tarja Katajisto for laboratory assistance, and to the other members of the project PELAG for their help with the water column sampling. Tom Andersen, Sanna Tanskanen, Markku Viitasalo, Anna Uitto and Paul Wassmann provided valuable advice and comments. The constructive remarks and suggestions of 3 anonymous referees are gratefully acknowledged. Maria Ekman-Ekebom kindly revised the English. This study is a contribution from the project PELAG and it was financed by the Academy of Finland

\section{LITERATURE CITED}

Berggreen U, Hansen B, Kiarboe T (1988) Food size spectra, ingestion and growth of the copepod Acartia tonsa during development: implications for determination of copepod production. Mar Biol 99:341-352

Blasco D (1978) Observations on the diel migration of marine dinotlagellates off the Baja California coast. Mar Biol 46: $41-47$

Bloesch J, Burns NM (1980) A critical review of sedimentation trap technique. Schweiz Z Hydrol 42:15-55 
Blomqvist SL, Håkansson L (1981) A review of sediment traps in aquatic environments. Arch Hydrobiol 91:101-132

Coale KH (1990) Labyrinth of doom: a device to minimize the 'swimmer' component in sediment trap collections. Limnol Oceanogr 35:1376-1381

Crawford DW (1989) Mesodinium rubrum: the phytoplankter that wasn't. Mar Ecol Prog Ser 58:161-174

Cullen JJ, Horrigan SG (1981) Effects of nitrate on the diurnal vertical migration, carbon to nitrogen ratio, and the photosynthetic capacity of the dinoflagellate Gymnodinium splendens. Mar Biol 62:81-89

Dale T (1989) Sedimentation of loricas of tintinnids /Ciliata, Protozoa) and shells of bivalve larvae in the landlocked fjord, Lindåspollene, Norway. Arch Protistenkd 137:45-55

Durbin EG, Durbin AG (1992) Effects of temperature and food abundance on grazing and short-term weight change in the marine copepod Acartia hudsonica. Limnol Oceanogr $37: 361-378$

Durbin AG, Durbin EG, Wlodarczyk E (1990) Diel feeding behaviour in the marine copepod Acartia tonsa in relation to food availability. Mar Ecol Prog Ser 68:23-45

Edler L (ed) (1979) Recommendations on methods for marine biological studies in the Baltic Sea Phytoplankton and chlorophyll. The Baltic Marine Biologists, Publ 5:1-38

Eppley RW, Holm-Hansen O, Strickland JDH (1968) Some observations on the vertical migration of dinoflagellates. J Phycol 4:333-340

Eppley RW, Renger EH, Becker PR (1983) The residence time of particulate organic carbon in the surface layer of the ocean. Deep Sea Res 30:311-323

Fallon RD, Brock TD (1979) Decomposition of blue-green algae (cyanobacterial) blooms in Lake Mendota, Wisconsin. Appl environ Microbiol 37:820-830

Fraga S, Gallager SM, Anderson DM (1989) Chain-forming dinoflagellates: an adaptation to red tides. In: Okaichi $T$, Anderson DM, Nemoto $T$ (eds) Red tides: biology, environmental science, and toxicology. Elsevier, New York, p 281-284

Gardner WD (1980) Field assesment of sediment traps. J mar Res 38:41-52

Gardner WD, Hinga KR, Marra J (1983) Observations on the degradation of biogenic material in the deep ocean with implications on accuracy of sediment trap fluxes. $J$ mar Res 41:195-214

Grasshoff K (ed) (1983) Methods of seawater analysis. Verlag Chemie, Weinheim

Haapala J (1994) Upwelling and its influence on nutrient concentration in the coastal area of the Hanko peninsula, entrance of the Gulf of Finland. Estuar coast Shelf Sci 38: $507-521$

Heaney SI, Butterwick C (1985) Comparative mechanisms of algal movement in relation to phytoplankton production. ln: Rankin MA (ed) Migration: mechanisms and adaptive significance. Contr mar Sci (Suppl) 27:114-134

Heaney SI, Eppley RW (1981) Light, temperature and nitrogen as interacting factors affecting diel vertical migrations of dinoflagellates in culture. J Plankton Res 3:331-344

Hedges JI, Clark WA, Cowie GL (1988) Fluxes and reactivities of organic matter in a coastal marine bay. Limnol Oceanogr 33:1137-1152

Hedges JI, Lee C, Wakeham SG, Hernes PJ, Peterson ML (1993) Effects of poisons and preservatives on the fluxes and elemental compositions of sediment trap materials. J mar Res 51:651-668

Heiskanen AS (1993) Mass encystment and sinking of dinoflagellates during a spring bloom. Mar Biol 116:161-167

Heiskanen AS, Kononen K (1994) Sedimentation of vernal and late summer phytoplankton communities in the coastal Baltic Sea. Arch Hydrobiol 131:175-198

Heiskanen AS, Leppänen JM (1995) Estimation of export production in the coastal Baltic Sea: effect of resuspension and microbial decomposition on sedimentation measurements. Hydrobiologia (in press)

Hicks GRF, Coull BC (1983) The ecology of marine meiobenthic harpacticoid copepods. Oceanogr mar biol A Rev 21 $67-175$

Iturriaga $R$ (1979) Bacterial activity related to sedimenting particulate matter. Mar Biol 55:157-169

Jonsson P R, Tiselius P (1990) Feeding behaviour, prey detection and capture efficiency of the copepod Acartia tonsa feeding on planktonic ciliates. Mar Ecol Prog Ser 60:35-44

Kamykowski D, McCollum S A (1986) The temperature acclimatized swimming speed of selected marine dinoflagellates. J Plankton Res 8:275-287

Kankaala P, Johansson S (1986) The influence of individual variation on length-biomass regressions in three crustacean zooplankton species. J Plankton Res 8:1027-1038

Kiorboe T, Mohlenberg F, Riisgård HU (1985) In situ feeding rates of planktonic copepods: a comparison of four methods. J exp mar Biol Ecol 88:67-81

Kleppel GS (1993) On the diets of calanoid copepods. Mar Ecol Prog Ser 99:183-195

Knauer RA, Karl DM, Martin HJ, Hunter CN (1984) In situ effects of selected preservatives and total carbon, nitrogen and metals collected in sediment traps. J mar Res 42 : $445-462$

Kononen K, Forsskåhl M, Huttunen M, Sandell M, Viljamaa $H$ (1984) Practical problems encountered in phytoplankton cell volume calculations using the $\mathrm{BMB}$ recommendation in the Gulf of Finland. Limnologica 15:605-614

Kuparinen J, Leppänen JM, Sarvala J, Sundberg A, Virtanen A. (1984) Production and utilization of organic matter in a Baltic ecosystem off Tvärminne, southwest coast of Finland. Rapp P-v Réun Cons int Explor Mer 183:180-192

Larsen J, Kuosa H, Ikävalko J, Kivi K. Hällfors S (1995) A redescription of Scrippsiella hangoei (Schiller) Comb. nov. - a 'red tide' forming dinoflagellate from the northern Baltic. Phycologia 34:135-144

Larsson U, Hobro R, Wulff $F$ (1986) Dynamics of a spring bloom in a coastal area of the Northern Baltic Proper. Contr Askö Lab, Univ Stockholm 30:1-32

Lee C. Hedges J I (1988) The measurement of oceanic particle flux - are 'swimmers' a problem? Oceanography 1:34-36

Lee C, Hedges JI, Wakeham ST, Zhu N (1992) Effectiveness of various treatments in retarding microbial activity in sediment trap material and their effects on the collection of swimmers. Limnol Oceanogr 37:117-130

Leedale GF (1967) Euglenoid flagellates. Prentice-Hall, Englewood Cliffs

Leppänen JM (1988) Cycling of organic matter during the vernal growth period in the open northern Baltic Proper VI. Sinking of particulate matter. Finn mar Res 255:97-118

Lignell R, Heiskanen AS, Kuosa H, Gundersen K, KuuppoLeinikki P, Pajuniemi R, Uitto A (1993) Fate of phytoplankton spring bloom: sedimentation and carbon flow in the planktonic food-web in the northern Baltic. Mar Ecol Prog Ser 94:239-252

Lindholm $T$ (1985) Mesodinium rubrum - a unique photosynthetic ciliate. Adv aquat Microbiol 3:1-48

Lorenzen CJ, Welschmayer NA, Copping AE, Vernet $M$ (1983) Sinking rates of organic particles. Limnol Oceanogr 28:766-769

Lund JWG, Kipling C, Le Cren ED (1958) The inverted microscope method of estimating algal numbers and the statisti- 
cal basis of estimations by counting. Hydrobiologia 11 : $143-170$

Michaels AF, Silver MW, Gowing MM, Knauer GA (1990) Cryptic zooplankton 'swimmers' in upper ocean sediment traps. Deep Sea Res 37:1285-1296

Mullin MM (1969) Production of zooplankton in the ocean: the present status and problems. Oceanogr mar biol A Rev $7: 293-314$

Passow U (1991) Vertical migration of Gonyaulax catenata and Mesodinium rubrum. Mar Biol 110:455-463

Peinert R, Saure A, Stegmann P, Stien C, Haardt H, Smetacek $\mathrm{V}$ (1982) Dynamics of primary production and sedimentation in a coastal ecosystem. Neth J Sea Res 16:276-289

Peterson ML, Hernes PJ, Thoreson DS, Hedges JI, Lee C, Wakeham SG (1993) Field evaluation of a valved sediment trap. Limnol Oceanogr 38:1741-1761

Peterson W, Dam H (1990) The influence of copepod 'swimmers' on pigment fluxes in brine-filled vs ambient seawater-filled sediment traps. Limnol Oceanogr 35:448-455

Reid PC, Boalch GT (1987) A new method for the identification of dinoflagellate cysts. J Plankton Res 9:249-253

Sicko-Goad L, Stoemer EF, Ladewski BG (1977) A morphometric method for correcting phytoplankton cell volume estimates. Protoplasma 93:147-163

Stoecker DK, Taniguchi A, Michaels AE (1989) Abundance of autotrophic, mixotrophic and heterotrophic planktonic ciliates in shelf and slope waters. Mar Ecol Prog Ser 50: $241-254$

Strathmann RR (1967) Estimating the organic carbon content

This article was presented by S. W. Fowler (Senior Editorial Advisor), Monaco of phytoplankton from cell volume or plasma volume. Limnol Oceanogr 12:411-418

Taguchi S, Hargrave B T (1978) Loss rates of suspended material sedimented in a marine bay. J Fish Res Bd Can 35 $1614-1620$

Tanskanen $S$ (1994) Seasonal variability in the individual carbon content of the calanoid copepod Acartia bifilosa from the northern Baltic Sea. Hydrobiologia 292/293:397-403

Taylor F J R (1978) Some specific preparations: dinoflagellates. In: Sournia A (ed) Phytoplankton manual. UNESCO monographs on oceanographic methodology 6. UNESCO, Paris, p 143-147

Throndsen J (1973) Motility in some marine nanoplankton flagellates. Norw J Zool 21:193-200

Throndsen J (1978) Preservation and storage. In: Sournia A (ed) Phytoplankton manual. UNESCO monographs on oceanographic methodology 6. UNESCO, Paris, p 69-74

Venrick E L (1978) How many cells to count? In: Sournia A (ed) Phytoplankton manual. UNESCO monographs on oceanographic methodology 6. UNESCO, Paris, p 167-180

Viitasalo M (1992) Mesozooplankton of the Gulf of Finland and northern Baltic proper - a review of the monitoring data. Ophelia 35:147-168

Wassmann P (1990) Relationship between primary and export production in the boreal coastal zone of the North Atlantic. Limnol Oceanogr 35:464-471

Wassmann P (1991) Dynamics of primary production and sedimentation in shallow tjords and polls ot western Norway. Oceanogr mar biol A Rev 29:87-154

Manuscript first received: April 29, 1994

Revised version accepted: January 1, 1995 